\title{
Viability and fertility of cooled equine semen diluted with skimmed milk or glycine egg yolk-based extenders
}

\section{Guilherme Pugliesi ${ }^{1}$, Giovanni Ribeiro de Carvalho ${ }^{1}$, Daniel Macêdo Rates ${ }^{2}$, Pedro Gama Ker ${ }^{1}$, Manuela Pereira da Matta ${ }^{2}$, Renan Reis de Oliveira ${ }^{1}$, José Monteiro da Silva Filho ${ }^{3}$}

\author{
${ }^{1}$ Department of Animal Science, Universidade Federal de Viçosa, Viçosa, MG, Brazil. \\ ${ }^{2}$ Department of Veterinary Medicine, Universidade Federal de Viçosa, Viçosa, MG, Brazil. \\ ${ }^{3}$ Department of Veterinary Clinics and Surgery, Universidade Federal de Minas Gerais, Belo Horizonte, MG, Brazil.
}

\begin{abstract}
Two semen extenders were compared for their ability to maintain viability of horse semen during 24 hours of cold preservation, and for the pregnancy rate after artificial insemination. In the experiment 1 , five ejaculates from three stallions were split-diluted in either a skimmed milk-based extender (Kenney extender) or a glycine egg yolk-based extender (Foote extender) and cooled at $6-8{ }^{\circ} \mathrm{C}$ for 24 hours. Semen samples stored in Kenney extender for 24 hours had higher motility and spermatic vigor compared with those stored in Foote extender. However, samples stored in Foote extender had higher number of reactive sperm by hypoosmotic test and greater viability by epifluorescence test compared with those in Kenney extender. In the experiment 2, 17 and 23 ejaculates from two stallions were split-diluted with Kenney extender and Foote extender. The sperm concentration in each extender was adjusted to 500 million viable sperms per insemination dose. Semen was cooled to $6-8{ }^{\circ} \mathrm{C}$ and stored for 24 hours. Seventy-four cycles of crossbred mares were inseminated with either semen diluted in Kenney extender or semen diluted in Foote extender. The pregnancy rate was higher from semen diluted in Kenney extender than that from semen in Foote extender ( 0.553 vs. 0.306). The Kenney extender is effective in preserving the motility, vigor and fertility of stallion semen after 24 hours of cold storage, whereas the Foote extender is not acceptable.
\end{abstract}

Key Words: artificial insemination, cooling, semen extender, stallion

\section{Introduction}

Artificial insemination with cooled semen has been routinely used in equine reproduction as it allows higher fertility rates compared with those with frozen semen, when used within 24 hours after collection (Jasko et al., 1992; Vidament et al., 1997; Aurich \& Aurich, 2006).

The semen extenders used for dilution and packaging of equine cooled semen are mostly based on skimmed milk and egg yolk. The active components involved in sperm protection by milk are casein micelles, which interact with membrane plasma proteins and protect against the removal of phospholipids and cholesterol from the plasma membrane (Bergeron \& Manjunath, 2006). The egg yolk, in combination with other components of extender, can help the sperms to resist the cold shock (Bogart \& Mayer, 1950; Amirat et al., 2004) and this protective action is mainly attributed to low-density lipoprotein (Pace \& Graham, 1974; Moussa et al., 2002).

The sperm plasma membrane in stallion and boar has a lower ratio of cholesterol to phospholipids than the bull sperm plasma membrane (Parks \& Lynch, 1992). This apparently results in more susceptibility of stallion and boar semen to cold shock during storage at low temperatures (Parks \& Lynch, 1992). In this regard, the semen extenders that are commonly used for cooling of boar semen may be adapted for use in storage of stallion cooled semen for better fertility results. A glycine egg yolk-based extender (Foote, 2002) was used for cooling of boar semen and the sperm motility did not decline more than $10 \%$ during 2 days of storage at various temperatures $\left(5,15\right.$ or $\left.25^{\circ} \mathrm{C}\right)$. The same extender maintained the fertility of donkey semen after dilution and cooling at $5{ }^{\circ} \mathrm{C}$ for 12 hours (Rossi et al., 2012), showing promising results for adaptation for use in cooling of stallion semen.

An estimate of potential fertility of semen sample can be obtained through several in vitro tests for evaluation of semen characteristics (Mocé \& Graham, 2008). Semen evaluation using these laboratory tests is rapid, inexpensive and extremely important for the artificial insemination practice to ensure high semen quality.

The objective of the present study was to evaluate and compare the in vitro viability and in vivo fertility of stallion semen stored at low temperature $\left(6-8{ }^{\circ} \mathrm{C}\right)$ for 24 hours using an extender (Kenney extender, a skimmed powdered milk-based extender; Kenney et al., 1975) that is 
commonly used in stallion semen dilution and an extender (Foote extender, a glycine-egg yolk-based extender; Foote, 2002) that is used for boar semen.

\section{Material and Methods}

In experiment 1 , three stallions of the Mangalarga Marchador breed, 8 to 14 years-old, were selected with no apparent abnormalities of the reproductive tract, as determined on the basis of andrological examination and reproductive history, and kept in $5 \times 3 \mathrm{~m}$ stalls. Stallions were fed elephant grass (Pennisetum purpureum), concentrate (corn and soybean), and mineral salt and were in good body condition during the period of semen collection for the experiment.

Semen samples were collected in December during the reproductive season in Brazil. Five ejaculates per stallions were used, collected three times a week with the aid of an artificial vagina (adapted Hannover model) using a mare in estrus as dummy. The ejaculates were immediately taken to the laboratory for further processing. Each ejaculate was split into two parts. One part was diluted in Kenney extender, a skimmed milk based extender (Kenney et al., 1975), commonly used for dilution of stallion semen. The other part was diluted in Foote extender, a glycine-egg yolk based extender (Foote, 2002) used for dilution of boar semen. After the dilution, both the parts were packaged in aliquots containing $12 \mathrm{~mL}$ of diluted semen with final concentration of $30 \times 10^{6}$ viable sperm $/ \mathrm{mL}$, and stored in a container (Equitainer ${ }^{\circledR}$; Hamilton Research, Inc. 66 Woodland Mead, South Hamilton, MA, USA) at $6-8{ }^{\circ} \mathrm{C}$ for 24 hours.

The semen quality was evaluated for fresh, diluted and cooled semen. The physical parameters of motility (number of sperm with progressive movement/100 sperm cells) and vigor (status of the sperm motility), scored on a scale from 0 (without movement) to 5 (fast progressive movement), were evaluated under a light microscope $(400 \times)$ by two trained evaluators who did not know the treatment groups. The sperm morphology of diluted and cooled semen was evaluated after deposition of one drop of semen, previously diluted in saline formaldehyde solution buffered at $37{ }^{\circ} \mathrm{C}$, between slide and cover slip. Counting of 200 sperm cells was done under an optical phase contrast microscope $(1000 \times)$ for enumeration of different types of morphological abnormalities (Brito, 2007; Varner, 2008) and subsequent classification for minor or major defects (Blom, 1972). The integrity of the plasma membrane was evaluated by supravital test and functionality by hyposmotic test (HOST) in the diluted semen before and after the cold storage. The supravital test was done using eosin-nigrosin stain. One drop $(10 \mu \mathrm{L})$ of semen was placed together with one drop $(10 \mu \mathrm{L})$ of dye on a slide, and a smear was made after 2 minutes on a hot plate at $37{ }^{\circ} \mathrm{C}$. The sperms classified as intact (viable) membrane were not stained by eosin, while the non-intact (nonviable) membrane showed the pink-red stained nuclei. From each one, a sample of 100 sperm cells were counted under common optical microscope (400×).

For HOST, a solution of $100 \mathrm{mOsmol}$ sucrose-base was used. Aliquots of $1 \mathrm{~mL}$ of this solution were placed in tubes at $37{ }^{\circ} \mathrm{C}$ and $20 \mu \mathrm{L}$ of semen sample were added and incubated for 50 minutes in a water bath at $37{ }^{\circ} \mathrm{C}$. Subsequently, the sperms were analyzed by counting 100 sperm cells from each sample in phase contrast microscopy $(400 \times)$. The cells were classified by the presence or absence of coiled tail (Neild, 1999). The calculations of hyposmotic reaction were done using the formula (reactive sperms by HOST $=\%$ of coiled tails after HOST $-\%$ of coiled tails before HOST) described by Melo \& Henry (1999).

The assessment of membrane integrity of the semen after 24 hours of cooling was also verified using the combination of two fluorescent dyes: propidium iodide (PI) and carboxyfluorescein diacetate (CFDA). Sperm showing complete or partial red fluorescence (PI staining) was considered nonviable, while sperm showing green fluorescence was considered viable (Brito, 2007). For CFDA/PI staining, $10 \mu \mathrm{L}$ of diluted semen after cold storage for 24 hours at $6-8{ }^{\circ} \mathrm{C}$ was added to a conical tube containing $40 \mathrm{~mL}$ of stock solution of CFDA/PI in a dark room at $25^{\circ} \mathrm{C}$. The reading was performed after the homogenization of the conical tube. The slides were prepared (wet preparation) at room temperature and evaluated in fluorescence microscope (1250×), using filters of 480 to $610 \mathrm{~nm}$ (fluorescein and rhodamine, respectively).

In experiment 2, the experiment was done from October to February during the reproductive season in Brazil. Semen ejaculates from 2 Mangalarga Marchador breed stallions, at 9 (Stallion 1) and 8 (Stallion 2) years of age, were used. The selection, feeding and management were similar to experiment 1.

To determine the fertility rate of the diluted and coldstored ejaculates after artificial insemination, 38 crossbred Breton-Postier mares, of 4 to 18 years of age, weighing 350 to $500 \mathrm{~kg}$ and with good body condition score were used. The mares were selected with no apparent abnormalities of the reproductive tract, as determined by ultrasound examinations and reproductive history (Ginther, 1995). The animals were kept in paddocks. Mares received mineral salt ad libitum and supplementation with shopped elephant grass (Pennisetum purpureum) and concentrate (corn and soybean). 
Seventeen ejaculates from Stallion 1 and 23 ejaculates from Stallion 2 were collected. The semen collections were done three times a week (Monday, Wednesday, and Friday), with the aid of an artificial vagina (adapted Hannover model) using a mare in estrus as dummy. After collection, the ejaculates were immediately taken to the laboratory for further processing. Each ejaculate was split into two parts and diluted either in Kenney or Foote extender. The dilution with extenders was performed as described in Experiment 1. The concentration of sperm was adjusted to 500 million viable sperms per insemination dose in a final volume of $15 \mathrm{~mL}$. The semen was placed in Equitainer ${ }^{\circledR}$ for cooling at $6-8^{\circ} \mathrm{C}$ for 24 hours. The mares were inseminated by semen dose either with Kenney or with Foote extender. Semen from two stallions was used randomly.

The semen quality was evaluated for fresh, diluted and cooled semen for physical and morphological characteristics as described in experiment 1.

The mares were regularly observed and examined, and those which showed estrous signs and/or a follicle greater than $25 \mathrm{~mm}$ in diameter, with good uterine conditions (no fluid in the uterine lumen and onset of endometrial edema) were daily monitored by transrectal palpation. After the detection of $30 \mathrm{~mm}$ follicles, mares were randomly assigned to two groups: mares inseminated with cooled semen in Kenney extender and mares inseminated with cooled semen in Foote extender. The semen from both stallions was randomly used among the mares. Inseminations were made only on predetermined days (3 times a week - Tuesdays, Thursdays and Saturdays). The semen was deposited in uterine body on the day of detection of a 30-40 mm follicle and repeated until observation of ovulation. Seventy-four estrous cycles from 38 mares were used. The pregnancy diagnosis was made from the 10th to the 13th day after the ovulation by transrectal ultrasonography (Ginther, 1995).

The dependent variables considered were: progressive motility, sperm vigor, sperm morphology, reactivity to HOST, number of viable and nonviable sperms by supravital dye test and number of viable and nonviable sperms by epifluorescence dye test. The data that showed a normal distribution by Shapiro-Wilk test were compared using ANOVA followed by the Student-Newman Keuls test for comparisons between extenders and between stallions. Data that were not normally distributed (spermatic vigor) were transformed to log. The simple Pearson correlation was tested among the variables (progressive motility, reactive to HOST, viable by epifluorescence and viable by supravital test) to verify the possible relationships between the characteristics after cooling. Pregnancy rate in mares was compared by the frequency distribution of Chi-square $\left(\mathrm{X}^{2}\right)$ to check for possible differences between extenders. The statistical software SAS was used (SAS Institute Inc, version 9.2). The data are given as the mean \pm SD unless otherwise indicated. A probability of $\mathrm{P}<0.05$ indicated that the difference was significant.

\section{Results and Discussion}

In experiment 1, the mean values of progressive motility and sperm vigor of the fresh semen were $62.7 \pm 9.3$ sperm/100 sperm and $3.2 \pm 0.3$, respectively and did not differ between stallions. For diluted semen before cold storage, there were no differences in any physical and morphological characteristics of sperms between the Kenney and Foote extenders (Table 1). For cooled semen (6-8 ${ }^{\circ} \mathrm{C}$ for 24 hours), progressive motility and sperm vigor of semen diluted with Kenney extender were higher $(\mathrm{P}<0.05)$ than that of semen diluted with Foote extender; no difference was found between the extenders in any sperm morphology characteristics. The percentage of sperm defects was higher $(\mathrm{P}<0.05)$ in the diluted semen after than before cooling, irrespective of extender.

In experiment 2 , the mean values of progressive motility and sperm vigor of the fresh semen were $69.9 \pm 5.0 \%$ and $3.4 \pm 0.3$, respectively, and did not differ between stallions. The mean percentage of progressive motility

Table 1 - Mean of data for physical and morphological characteristics of stallion semen diluted in Kenney extender or Foote extender and stored at $6-8{ }^{\circ} \mathrm{C}$ for 24 hours

\begin{tabular}{|c|c|c|c|c|}
\hline \multirow{2}{*}{ Parameter $(n=15)$} & \multicolumn{2}{|c|}{ Diluted $^{1}$} & \multicolumn{2}{|c|}{ Cooled $^{2}$} \\
\hline & Kenney & Foote & Kenney & Foote \\
\hline Progressive motility (sperm/100 sperm) & $62.3 \pm 9.6$ & $60.0 \pm 11.0$ & $37.0 \pm 9.4 \mathrm{a}$ & $30.3 \pm 11.0 \mathrm{~b}$ \\
\hline Sperm vigor $(0-5)$ & $3.4 \pm 0.4$ & $3.1 \pm 0.3$ & $2.4 \pm 0.3 \mathrm{a}$ & $2.0 \pm 0.5 b$ \\
\hline Normal sperm (sperm/100 sperm) & $71.3 \pm 7.5 x$ & $72.0 \pm 8.8 x$ & $65.7 \pm 8.7 y$ & $67.7 \pm 9.8 y$ \\
\hline Major defects (sperm/100 sperm) & $8.8 \pm 3.8$ & $7.1 \pm 3.0$ & $9.3 \pm 5.3$ & $7.9 \pm 5.0$ \\
\hline Minor defects (sperm/100 sperm) & $20.0 \pm 7.8 y$ & $22.2 \pm 9.7 y$ & $25.0 \pm 7.8 \mathrm{x}$ & $24.6 \pm 10.9 x$ \\
\hline
\end{tabular}

$\mathrm{a}, \mathrm{b}$ - Means with different letters $(\mathrm{a}, \mathrm{b})$ in the same row within each semen category (diluted or cooled) differ $(\mathrm{P}<0.05)$

$\mathrm{x}, \mathrm{y}-$ Means with different letters $(\mathrm{x}, \mathrm{y})$ in the same row within each semen extender (Kenney or Foote) differ $(\mathrm{P}<0.05)$.

${ }^{1}$ Semen before cooling.

${ }^{2}$ Semen after cooling at $6-8{ }^{\circ} \mathrm{C}$ for 24 hours. 
and sperm vigor of cooled semen were higher $(\mathrm{P}<0.05)$ in Kenney extender $(51.0 \pm 10.5$ sperm/100 sperm and $3.0 \pm 0.4$,

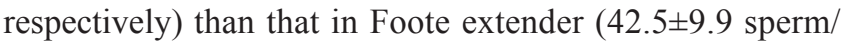
100 sperm and $2.4 \pm 0.5$, respectively). The mean values of number of normal sperm/100 sperm in fresh semen (before dilution), semen cooled with Kenney extender, and semen cooled with Foote extender were $73.4 \pm 4.3 ; 63.0 \pm 11.1$; and $64.2 \pm 14.5$, respectively. The mean number of normal sperm/ 100 sperm after cooling at $6-8{ }^{\circ} \mathrm{C}$ for 24 hours was lower $(\mathrm{P}<0.05)$ in both extenders by the morphology test, but there was no significant difference between extenders. After cooling for 24 hours, the semen diluted in both extenders showed a higher $(\mathrm{P}<0.05)$ number of sperm with minor defects compared with those of fresh semen (unpublished data).

The significant higher progressive motility and sperm vigor obtained with Kenney extender in both experiments is probably due to better availability of substrate in this extender (glucose-skimmed milk) in comparison with Foote extender (glycine-egg yolk), a characteristic that provides greater energy support for survival and movement of spermatic cell. Changes in organization of the plasma membrane fluid mosaic can lead to alterations in permeability, functionality and metabolism of sperm cell, which may affect the motility and fertilizing ability (Amann \& Graham, 1993). Although the protection mechanism of milk for the sperm is not clearly known, it is believed that phosphocaseinate and $\beta$-lactoglobulin are the major components of milk that promote this protection (Batellier et al., 1998; 2001). Another factor that may be correlated to the survival of sperm cells during storage is the amount of energy reserves contained in extender and seminal plasma, which, in the case of exhaustion of reserves, could promote sperm metabolic death, since motility is the process that requires more energy and has a positive correlation with ATP concentrations (Heisnaken et al., 1987; Januaskauskas \& Rodriguez-Martinez, 1995). The previous studies using egg yolk in equine semen extenders were equivocal. Some studies (Province et al., 1984; Bruemmer et al., 2002) showed inferiority of egg yolk-based extenders and others (Rota et al., 2004; Melo et al., 2005; Rota et al., 2008) showed superiority of yolk-based extenders on the motility and viability at different periods of storage in comparison with those from milk-based extenders.

Although there was no difference in the number of normal and defective sperms between extenders after cooling in both experiments, the number of sperm defects increased with both extenders compared with fresh diluted semen, and this reinforces the previous studies (Graham, 1996) in which the cooling process promoted irreversible cellular injuries, which may impair the semen fertility. However, the increase was mostly in minor defects and could have been promoted by cold shock. These defects are considered less important than the major defects when considering fertility, and can be compensated by increasing sperm number in insemination dose (Chenoweth, 2005).

In experiment 1 , there were no significant differences in the functionality of sperm plasma membrane by HOST and integrity by supravital staining in diluted semen before cooling between Kenney and Foote extenders (Table 2). The data for epifluorescence test on cooled semen was not available in 3 samples in each extender due to lack of semen evaluation within two hours after staining with the fluorescent probes. For cooled semen after 24 hours at 6-8 ${ }^{\circ} \mathrm{C}$, sperm functionality by HOST and the integrity by epifluoresence was higher $(\mathrm{P}<0.05)$ in Foote extender compared with that of Kenney extender; the supravital viability did not differ between extenders. A significant $(\mathrm{P}<0.05)$ correlation was observed between HOST and epifluorescence test $(r=0.46)$ and between HOST and supravital test $(r=0.39)$ combined for extenders (data not shown). No correlations were observed between any other characteristics.

The plasma membrane allows selective transport of important molecules to the sperm cytoplasm and its integrity is important for the reactions necessary for union of male and female gametes (Jeyendran et al., 1984). The two

Table 2 - Mean of data for the number of reactive sperm by HOST, and viable sperm by supravital and epifluorescence test in stallion semen diluted in Kenney extender or Foote extender and stored at $6-8^{\circ} \mathrm{C}$ for 24 hours

\begin{tabular}{|c|c|c|c|c|}
\hline \multirow{2}{*}{ Parameter $(n=15)^{3}$} & \multicolumn{2}{|c|}{ Diluted $^{1}$} & \multicolumn{2}{|c|}{ Cooled $^{2}$} \\
\hline & Kenney & Foote & Kenney & Foote \\
\hline HOST (reactive sperm/100 sperm) & $47.5 \pm 15.7$ & $59.2 \pm 13.3$ & $23.6 \pm 11.3 \mathrm{a}$ & $39.9 \pm 14.0 \mathrm{~b}$ \\
\hline Supravital (viable sperm/100 sperm) & $61.6 \pm 5.3$ & $72.8 \pm 8.6$ & $34.9 \pm 22.9$ & $47.8 \pm 21.4$ \\
\hline Epifluorescence (viable sperm/100 sperm) & - & - & $22.5 \pm 20.3 \mathrm{a}$ & $61.0 \pm 14.0 \mathrm{~b}$ \\
\hline
\end{tabular}

Means with different letters in the same row within each semen category (diluted or cooled) differ $(\mathrm{P}<0.05)$.

HOST - hyposmotic test.

${ }^{1}$ Semen before cooling.

${ }^{2}$ Semen after cooling at $6-8{ }^{\circ} \mathrm{C}$ for 24 hours.

${ }^{3}$ For epifluorescence test for cooled semen $n=12$. 
extenders were similar in their effect on plasma membrane integrity of cooled sperm by supravital test. However, other studies have shown superiority in the number of viable sperm (range 72 to 90 sperm/100 sperm) by supravital test in extenders containing egg yolk (Melo \& Henry, 1999; Nunes et al., 2008). The superiority of Foote extender by the HOST and epifluorescence test suggested that it may give better protection to the plasma membrane during cooling. However, this apparently could not compensate the simultaneous impairment of the motility and vigor of the sperms as shown by the lower pregnancy rate from the semen diluted in Foote extender (Table 3). The decrease in motility in the cooled semen in Foote extender may be attributed to changes in available energy or damage to elements of axoneme that may compromise progressive sperm motility without promoting high injury rate in the plasma membrane (Watson, 1995).

The sperm motility and morphology were the characteristics that best correlated to fertility of the semen in some studies (Dowsett et al., 1984; Daels et al., 1991; Jasko et al., 1992). In addition, in another study (Johansson et al., 2008) a positive correlation between sperm viability by supravital test and sperm motility were observed in stallion semen. In contrast with the present study, an association between sperm motility and integrity or functionality of its plasma membrane was not found. In this regard, for an effective evaluation of semen samples, several in vitro tests for different sperm characteristics are required. Since the process of fertilization of an oocyte by a sperm is complex, an in vitro test for measuring a single attribute of sperm may not be a foolproof method to assess the quality of semen. Further studies are indicated for the comprehensive examination of different forms of damage in the sperm during the cooling that impair the fertility of the semen.

The pregnancy rate did not differ significantly between stallions 1 and 2, combined for the two extenders (Table 3). Thus, data from the two stallions was combined. The pregnancy rate was higher $(\mathrm{P}<0.05)$ for semen with Kenney extender than that for Foote extender.

Table 3 - Pregnancy rates (number of pregnancy/cycle) of mares inseminated with stallion semen diluted and cooled in Kenney extender or Foote extender at $6-8{ }^{\circ} \mathrm{C}$ for 24 hours

\begin{tabular}{lcc}
\hline & Kenney $(\mathrm{n}=38)$ & Foote $(\mathrm{n}=36)$ \\
\hline Stallion 1 & $0.438(7 / 16)$ & $0.267(4 / 15)$ \\
Stallion 2 & $0.636(14 / 22)$ & $0.333(7 / 21)$ \\
Overall & $0.553 \mathrm{a}(21 / 38)$ & $0.306 \mathrm{~b}(11 / 36)$ \\
\hline
\end{tabular}

Percentages with different letters in the same row differ $(\mathrm{P}<0.05)$.
The higher pregnancy rate observed with the Kenney extender (21/38 cycles) compared with the Foote extender (11/36 cycles) is consistent with higher motility and vigor observed in vitro for the Kenney extender in both experiments and indicates a better relationship between these characteristics with fertility than plasma membrane assessments. The lower pregnancy rate in semen diluted with Foote extender could also be due to presence of egg yolk, which has been shown to contain progesterone (mean of immunoreactive progesterone, $13.7 \pm 2.9 \mathrm{mg} /$ yolk; Möstl et al., 2001). Progesterone could lead to a premature sperm capacitation, leading to reduced fertility. Progesterone can bind to receptors on plasma membrane of equine sperm (Cheng et al., 1998), an important step in the acrosomal reaction process. The fertility obtained in this study with Kenney extender was similar to those obtained in many studies using milk-based extenders (Douglas-Hamilton et al., 1984; Jasko et al., 1992; Batellier et al., 1998).

The pregnancy rate for the semen with Foote extender was lower compared with that reported by others (Carvalho et al., 1997; Silva Filho et al., 1998; Melo et al., 2005) who also used egg yolk-based extenders. Thus, adaptations or modifications of Foote extender for the dilution of stallion semen may be a topic for further studies so as to improve the maintenance and protective ability of this semen extender. The possible modifications could be the addition of larger amounts of an energy constituent such as glucose to provide more energy in the form of ATP and thus avoid the metabolic death of the sperm.

\section{Conclusions}

Foote extender, a glycine-egg yolk-based semen extender, is not effective in preserving the semen characteristics (progressive motility and sperm vigor) and does not give acceptable fertility rate after insemination with diluted equine semen cooled to $6-8{ }^{\circ} \mathrm{C}$ for 24 hours. On the other hand, the Kenney extender is a superior option for diluting equine semen in programs of artificial insemination with cooled semen.

\section{Acknowledgments}

This experiment was carried out at the Equine Sector of Universidade Federal de Viçosa, Brazil, with support from CNPq, FAPEMIG and CAPES. The authors thank Dr. M. A. Beg, from University of Wisconsin for suggestions and Dr. A. M. Borges, from Universidade Federal de Minas Gerais for assistance with measurement of extender osmolarity. 


\section{References}

AMANN, R.P.; GRAHAM, J.K. Spermatozoa functional. In: MCKINNON, A.O.; VOSS, J.L. (Eds.) Equine reproduction. 1.ed. Philadelphia: Lea and Febiger, 1993. p.715-745.

AMIRAT, L.; TAINTURIER, D.; JEANNEAU, L. et al. Bull semen in vitro fertility after cryopreservation using egg yolk LDL: a comparison with optidyl, a commercial egg yolk extender. Theriogenology, v.61, p.895-907, 2004.

AURICH, J.; AURICH, C. Developments in European horse breeding and consequences for veterinarians in equine reproduction. Reproduction in Domestic Animals, v.41, p. 275-279, 2006.

BATELLIER, F.; DUCHAMP, G.; VIDAMENT, M. et al. Delayed insemination is successful with a new extender for storing fresh equine semen at $15^{\circ} \mathrm{C}$ under aerobic conditions. Theriogenology, v.50, p.229-236, 1998.

BATELLIER, F.; VIDAMENT, M.; FAUQUANT, J. et al. Advances in cooled semen technology. Animal Reproduction Science, v.68, p.181-190, 2001.

BERGERON, A.; MANJUNATH, P. New insights towards understanding the mechanisms of sperm protection by egg yolk and milk. Molecular Reproductive Development, v.73, p.1338-1344, 2006.

BLOM, E. The ultrastructure of some characteristic sperm defects and a proposal for a new classification on the bull spermiogram. In: SIMPOSIO INT DI ZOOTECHINIA, 7., 1972, Milan. Proceedings... Milan, 1972. p.125-139.

BOGART, R.; MAYER, D.T. The effects of egg yolk on the various physical and chemical factors detrimental to spermatozoan viability. Journal of Animal Science, v.9, p.143-152, 1950.

BRITO, L.F.C. Evaluation of stallion sperm morphology. Clinical and Technology in Equine Practice, v.6, p.249-264, 2007.

BRUEMMER, J.E.; COY, R.C.; SQUIRES, E.L. et al. Effect of pyruvate on the function of stallion spermatozoa stored for up to 48 hours. Journal of Animal Science, v.80, p.12-18, 2002.

CARVALHO, G.R.; SILVA FILHO, J.M.; FONSECA, F.A. Fertilidade do sêmen eqüino diluído, resfriado a $20^{\circ} \mathrm{C}$ e transportado. Revista Brasileira de Zootecnia, v.26, p.473-478, 1997.

CHENG, F.P.; FAZELI, A.R.; HAGE, W.J. et al. Progesterone-induced acrosome reaction in stallion spermatozoa is mediated by a plasma membrane progesterone receptor. Biology of Reproduction, v.59, p.733-742, 1998.

CHENOWETH, P.J. Genetic sperm defects. Theriogenology, v.64, p.457-468, 2005

DAELS, P.F.; HUGHES, J.P.; STABENFELDT, G.H. Reproduction in horses. In: CUPPS, P.T. (Ed.) Reproduction in domestic animals. 4.ed. San Diego: Academic, 1991. p.413-444.

DOUGLAS-HAMILTON, D.H.; OSOL, R.; OSOL, G. et al. A field study of fertility of transported equine semen. Theriogenology, v.22, p.291-304, 1984.

DOWSETT, K.F.; OSBORNE, H.G.; PATTIE, W.A. Morphological characteristics of stallion's spermatozoa. Theriogenology, v.22, p.463-472, 1984.

FOOTE, R.H. Within-herd use of boar semen at $5{ }^{\circ} \mathrm{C}$, with a note on eletronic monitoring of oestrus. Reproduction in Domestic Animals, v.37, p.62-63, 2002.

GINTHER, O.J. Ultrasonic imaging and animal reproduction: Book 2, Horses. Cross Plains, WI: Equiservices Publishing, 1995. $394 p$.

GRAHAM, J.K. Cryopreservation of stallion spermatozoa. Veterinary Clinic in North American: Equine Practice, v.12, p.131-147, 1996.

HEISNAKEN, M.L.; PIRHONEN, A.; KOSKINEN, E. et al. Motility and ATP content of extended equine spermatozoa in different storage conditions. Journal of Reproduction and Fertility, v.35 (Suppl), p.103-110, 1987.
JANUSKAUSKAS, A.; RODRIGUEZ-MARTINEZ, H. Assessment of sperm viability by measurement of ATP, membrane integrity and moyility in frozen/thawed bull semen. Acta Veterinary Scandnava, v.36, p.571-574, 1995.

JASKO, D.J.; SQUIRES, E.L.; MORAN, D.M. et al. Comparison of pregnancy rates utilizing fresh, cooled and frozen semen. In: INTERNATIONAL CONGRESS ANIMAL REPRODUCTION, 12., 1992, Haugue. Proceedings... Hague, Netherlands, 1992. p.649-660.

JEYENDRAN, R.S.; VAN der VEN, H.H.; PEREZ-PELADEZ, M. et al. Development of an assay to assess the functional integrity of human sperm membrane and its ralationship to other characteristcs. Journal of Reproduction and Fertility, v.70, p.219-228, 1984.

JOHANSSON, C.S.; MATSSON, F.C.; LEHN-JENSEN, H. et al. Equine spermatozoa viability comparing the NucleoCounter SP100 and the eosin-nigrosin stain. Animal Reproduction Science, v.107, p.325-326, 2008.

KENNEY, R.M.; BERGMAN, R.V.; COOPER, W.L. Minimal contamination techniques and preliminary findings. In: ANNUAL CONFERENCE OF AMERICAN ASSOCIATION OF EQUINE PRACTITIONERS, 1975, Boston. Proceedings... Boston, 1975. v.21, p.327-336.

MELO, M.I.V.; HENRY, M.; BEKER, A.R.C.L. Teste hiposmótico para avaliação da viabilidade do sêmen eqüino resfriado com diferentes diluidores. Arquivo Brasileiro de Medicina Veterinária e Zootecnia, v.57, p.757-763, 2005.

MELO, M.I.V.; HENRY, M. Teste hiposmótico na avaliação do sêmen equino. Arquivo Brasileiro de Medicina Veterinária e Zootecnia, v.51, p.71-78, 1999.

MOCÉ, E.; GRAHAM, J.K. In vitro evaluation of sperm quality. Animal Reproduction Science, v.105, p.104-108, 2008.

MÖSTL, E.; SPENDIER, H.; KOTRSCHAL, H. Concentration of immunoreactive progesterone and androgens in the yolk of hen's eggs (Gallus domesticus). Veterinary Medicine Austria, v.88, p.62-65, 2001.

MOUSSA, M.; MARINET, V.; TRIMECHE, A. et al. Low density lipoproteins extracted from hen egg yolk by an easy method: cryoprotective effect on frozen-thawed bull semen. Theriogenology, v.57, p.1695-1706, 2002.

NEILD, D.M.; CHAVES, M.G.; FLORES, M. et al. Hypoosmotic test in equine spermatozoa. Theriogenology, v.51, p.721-727, 1999.

NUNES, D.B.; ZORZATTO, J.R.; COSTA SILVA, E.V. Efficiency of short-term storage of equine semen in a simple-design cooling system. Animal Reproduction Science, v.104, p.434-439, 2008.

PACE, M.M.; GRAHAM, E.F. Components in egg yolk which protect bovine spermatozoa during freezing. Journal of Animal Science, v.39, p.1144-1149, 1974.

PARKS, J.E.; LYNCH, D.V. Lipid composition and thermotropic phase behavior of boar, bull, stallion, and rooster sperm membranes. Cryobiology, v.29, p.255-256, 1992.

PROVINCE, C.A.; AMANN, R.P.; PICKETT, B.W. et al. Extenders for preservation of canine and equine spermatozoa at $5{ }^{\circ} \mathrm{C}$. Theriogenology, v.22, p.409-415, 1984.

ROSSI, R.; SILVA FILHO, J.M.; PALHARES, M. et al. Efeito do número de inseminações artificiais sobre a fertilidade de éguas inseminadas com sêmen asinino diluído e resfriado a $5^{\circ} \mathrm{C}$ por 12 horas de armazenamento. Arquivo Brasileiro de Medicina Veterinária e Zootecnia, v.64, p.114-119, 2012.

ROTA, A.; FURZI, C.; PANZANI, D. et al. Studies on motility and fertility of cooled stallion spermatozoa. Reproduction in Domestic Animals, v.39, p.103-109, 2004.

ROTA, A.; MAGELLI, C.; PANZANI, D. et al. Effect of extender, centrifugation and removal of seminal plasma on cooled-preserved Amiata donkey spermatozoa. Theriogenology, v.69, p.176-185, 2008. 
SILVA FILHO, J.M.; FONSECA, F.A.; PALHARES, M.S. et al. Efeito de diferentes diluidores na fertilidade de éguas de diferentes Haras inseminadas com sêmen diluído, resfriado e transportado em contêiner especial. Revista Brasileira de Zootecnia, v.27, p.75-86, 1998.

VARNER, D.D. Developments in stallion semen evaluation. Theriogenology, v.70, p.448-462, 2008.
VIDAMENT, M.; DUPERE, A.M.; JULIENNE, P. et al. Equine frozen semen: freezability and fertility field results. Theriogenology, v.48, p.907-917, 1997.

WATSON, PF. Recent developments and concepts in the cryopreservation of spermatozoa and the assessment of their postthawing function. Journal of Reproduction and Fertility, v.7, p.871-891, 1995. 